Niniejsza publikacja jest dostępna na licencji Creative Commons. Uznanie autorstwa-Użycie niekomercyjne-Bez utworów zależnych 3.0 Polska. Pewne prawa zastrzeżone na rzecz autora. Zezwala się na wykorzystanie publikacji zgodnie z licencja - pod warunkiem zachowania niniejszej informacji licencyjnej oraz wskazania autora jako właściciela praw do tekstu. Treść licencji jest dostępna na stronie: http:// creativecommons.org/licenses/ by-nc-nd/3.0/ pl/

Lingwistyka Stosowana 16: 3/2016, 165-190

\author{
Magda ŻELAZOWSKA
}

Uniwersytet Warszawski

Magdalena ZABIELSKA

Uniwersytet im. Adama Mickiewicza w Poznaniu

\title{
Opis przypadku jako tekst specjalistyczny w dyskursie medycznym - przegląd badań
}

\begin{abstract}
:
The case report as a specialised text in medical discourse - review of the literature

This paper is an attempt to present and systematise knowledge on the genre of the case report, and to compare its different varieties in terms of their structure and language (traditional case reports, evidencebased case reports, integrated and interactive ones, "Patient Experience" series, "Case Challenge" series, letters to the editor about a case, and, not common in Poland - medical images/ flashlights, etc.). The theoretical part of this paper consists of a definition and characteristic features of the genre, its short historical outline, descriptions of case report forms and a review of the literature. The empirical part presents the analysis of English and Polish case reports from prestigious scientific medical journals and medical websites. The analysis of the data collected concerns their rhetorical and linguistic aspects.
\end{abstract}

\section{Wprowadzenie}

Opis przypadku jest jedną z najstarszych form komunikacji w medycynie. Celem niniejszej pracy jest próba zebrania i usystematyzowania wiedzy na temat medycznego opisu przypadku jako gatunku, porównania jego odmian pod względem strukturalnojęzykowym (tradycyjne opisy przypadków, opisy przypadków oparte na faktach, opisy łączące fakty oraz subiektywne relacje pacjenta i lekarza, opisy interaktywne, seria "Patient Experience", tzw. "Case Challenges" i inne serie o charakterze edukacyjnym, listy do redakcji zawierające opisy przypadków, a także mniej znane w Polsce formy skrótowe (ang. medical images/ flashlights), oraz nakreślenia współczesnych kierunków jego rozwoju. Praca składa się z części teoretycznej, zawierającej definicję, opis struktury i cech charakterystycznych opisu przypadku, krótką historię tegoż gatunku oraz opis jego współczesnych odmian. Ponadto autorki dokonały przeglądu literatury na temat opisu przypadku, uwzględniającej różne perspektywy, tj. językoznawstwo, nauki o zdrowiu, edukację medyczną itp. Materiał badawczy w części praktycznej stanowiły polskie i angielskie opisy przypadków z różnych dziedzin, ukazujące się w czasopismach polsko- i anglojęzycznych, m.in.: British Medical Journal, Journal of Medical Case Reports, Nowa Audiofonologia, Otolaryngologia Polska, Przypadkime- 
dyczne.pl oraz te publikowane w Internecie, w szczególności na portalu Medscape. Materiał badawczy został poddany analizie porównawczej, na podstawie której przedstawiono charakterystyczne cechy, podobieństwa i różnice oraz role, jakie pełnią poszczególne odmiany tego gatunku.

\section{Tlo teoretyczne}

Opis przypadku (ang. case report) jest jednym z reprezentantów tekstów specjalistycznych w dyskursie naukowym, którego adresatami są lekarze-praktycy, a także studenci kierunków medycznych i początkujący specjaliści. Stanowi on rodzaj publikacji, której celem jest przedstawienie choroby o nieznanej etiologii lub wcześniej zdiagnozowanej, ale charakteryzującej się nietypowym przebiegiem i objawami, oraz zobrazowanie nowatorskiego podejścia do jej leczenia, pojawiających się trudności diagnostycznych i klinicznych, a także wskazanie wcześniej popełnianych błędów lekarskich, ich przyczyn oraz konsekwencji (B. Green/ C. Johnson 2006: 73-74). Jak podają T. Nissen i R. Wynn (2012: 87, thum. M. Ż.), opis przypadku jest ,dokładnym opisem doświadczeń pojedynczego pacjenta" oraz ",formalnym streszczeniem nietypowej choroby pacjenta, zawierajacym przedstawienie objawów i symptomów, badań diagnostycznych, procesu leczenia i zaleceń". Opis przypadku stanowi zazwyczaj pierwszą formę aktywności naukowej studentów i młodych lekarzy (np. G. Har-el 1999: 788), ma także niedocenianą wartość edukacyjną (zob. B. Charlton/F. Walston 1998: 147).

Na szczególne podkreślenie zasługuje fakt, iż informacja w nim zawarta może przyczynić się do szybszego i efektywniejszego rozwiązania podobnych problemów klinicznych w przyszłości, co ma swoje przełożenie na ratowanie zdrowia i życia pacjentów (K. Krzemieniecki 2010: 85). Wśród gatunków należących do mikro-gatunku (ang. micro-genre, J.R. Martin 1995) rodziny opisu przypadku wyróżnić można formy pochodne (ang. familial elemental genres, J.R. Martin 2000: 16) takie jak: tradycyjny opis przypadku, historia przypadku (pacjenta), notatki i prezentacja dotyczące przypadku, które to pozwalają specjalistom nie tylko z jednej ale i różnych instytucji na zbudowanie taktyki diagnostyki i leczenia oraz opieki nad danym pacjentem (S. Sarangi/ L. Brookes-Howell 2006: 197). Pomimo iż treść i zastosowanie powyższych form mogą być różne, to wszystkie one mają charakter opisowy i wyjaśniający dane zjawisko (F. Salager-Meyer et al. 1989: 155). W literaturze anglojęzycznej, oprócz nazwy „medyczny opis przypadku”, pojawiają się takie określenia tego gatunku, jak „kliniczny opis przypadku” (ang. clinical case report), „opis przypadku pojedynczego pacjenta” (ang. single-pacjent case report) lub „pojedynczy opis przypadku” (ang. single case report). Jeśli dotyczy on więcej niż jednego przypadku nazywać się może „serią przypadków" (ang. case series lub case series report). Zbiorowy opis przypadku odnosi się zazwyczaj do przedziału od 3 do 10 przypadków występowania jednej choroby (T. Nissen/ R. Wynn 2012: 87).

Po krótkim przedstawieniu charakterystyki tego gatunku, warto przybliżyć jego historię i rozwój na przestrzeni wieków. Jak podaje K. Krzemieniecki (2010: 85), opis przypadku jest najstarszą formą komunikacji w dziedzinie medycyny. Pierwsze opisy przypadków pochodzą z czasów Starożytnego Egiptu (zob. E. Dib/ M. Kidd/ D. Saltman 2008: 1), gdzie stanowiły podstawowe źródło wiedzy lekarza. Przez długi czas były też niczym więcej, niż formą komunikacji medyków - rozmową lub pisemną 
notatką - o nietypowym lub interesującym pacjencie w ich praktyce lekarskiej. Ten rodzaj luźnej rozmowy w formie opowiastek został zmodyfikowany i uznany za swego rodzaju dyskurs akademicki (H. Carleton/ M. Webb 2012: 93). Warto również zaznaczyć, iż w swym charakterze gatunek ten ewoluował od dokumentów jako prawna dokumentacja (łac. consilia) (J. Agrimi/ C. Crisciani 1994: 19) oraz raportów przedstawiających sensacyjne historie, mające na celu wzbudzić zainteresowanie czytelnika (B. Hurwitz 2006: 225), do współczesnych, bezosobowych i nastawionych tylko na omówienie zamierzonego zagadnienia opisów, opartych na paradygmacie biomedycznym. Pod koniec lat 70-tych XX wieku gatunek ten zaczął pojawiać się w czasopismach medycznych, jednak wraz z rozwojem medycyny, jego zastosowanie ograniczone zostało głównie do celów pedagogicznych, bycia swego rodzaju ,kamieniami szlachetnymi" opowiadającymi o rzadkich przypadkach (N. Papanas/ M.K. Lazarides 2008). Spowodowane to było pojawieniem się nowoczesnych metod diagnozy i leczenia, a także wprowadzeniem i rozwojem modelu, który to skupiał się pojmowaniu medycyny ściśle opartej na faktach i dowodach, potwierdzonej badaniami (ang. evidencebased medicine). Miało to swoje odzwierciedlenie w praktykach redakcyjnych, kiedy to w latach 80-tych XX wieku wiele czasopism medycznych rozpoczęło praktykę umniejszania roli opisów przypadków i umieszczania ich w sekcjach „Listy do redakcji”.

Po roku 1990 gatunek ten zaczął odzyskiwać swoje znaczenie i prestiż, dlatego też wiele czasopism dodawało specjalne rubryki, poświęcone tylko opisowi przypadku. Przykładami mogą być The Lancet i wprowadzona w 1997 roku sekcja Case Reports, American Journal of Psychiatry i wprowadzona samym roku Clinical Case Conference, British Medical Journal, a także dokonania G.P. Browmana (1999) w Journal of Clinical Oncology, który to pokazał, że jest możliwym uwzględnienie interesu i preferencji pacjenta $\mathrm{w}$ leczeniu nowotworu, nawet gdy stoją one $\mathrm{w}$ sprzecznosci z założeniami medycyny opartej na faktach. $\mathrm{Z}$ czasem powstały też czasopisma publikujące jedynie ten gatunek, m.in. BMJ Case Reports, Case Reports and Clinical Practice Review, Case Reports in Anethesiology, Case Reports in Dermatology, Case Reports in Medicine, Case Reports in Pediatrics, Clinical Case Reports oraz wiele innych. Większość czasopism polskojęzycznych z różnych dziedzin również zawiera sekcję poświęconą temu gatunkowi, m.in. Medycyna Rodzinna, Otolaryngologia Polska oraz Medycyna Paliatywna. Od 2007 roku medyczne opisy przypadków dostępne są już nie tylko w drukowanych wersjach czasopism, ale także w otwartym dostępie internetowym, czemu swój początek dały British Medical Journal i International Journal of Surgery Case Reports (T. Nissen/ R. Wynn 2012: 87-90).

Ponowne zainteresowanie tym gatunkiem wpłynęło również na wprowadzenie nowych odmian opisu przypadku, dostosowanych do zmian w komunikacji lekarz pacjent i ich wzajemnych relacji: opisy przypadków oparte na faktach, opisy łączące fakty oraz subiektywne relacje pacjenta i lekarza, opisy interaktywne, seria "Patient Experience", tzw. "Case Challenges" i inne serie o charakterze edukacyjnym, listy do redakcji zawierające opisy przypadków, a także mniej znane w Polsce formy skrótowe (P. Czapiewski 2015: 285).

Jak zauważają T. Nissen i R. Wynn (2014), koniec dwudziestego wieku okazał się nowym początkiem dla badanego gatunku z dwóch głównych powodów. Po pierwsze, 
to rosnące zainteresowanie tzw. badaniami narracyjnymi (ang. narrative studies) $\mathrm{z}$ perspektywy jakościowej (A. Barusch 2012), które zaowocowało, między innymi, ponownym zainteresowaniem publikacjami $\mathrm{w}$ specjalistycznych czasopismach medycznych, opartymi na opowieściach oraz licznymi nowymi inicjatywami (zob. np. sekcję Perspektywa pacjenta $\mathrm{w}$ interaktywnej odmianie opisu przypadku przedstawionej poniżej). Po drugie, to również sama popularność gatunku, który, pomimo iż nie jest postrzegany jako naukowy, ma swoich zagorzałych czytelników (R. Agha/ D.R. Rosin 2010). Dzieje się tak, ponieważ skupia się on na konkretnym pacjencie, co z kolei jest podstawą współczesnej praktyki medycznej, szczególnie z perspektywy modelu zorientowanego na pacjenta (ang. patient-centred model) W kolejnej sekcji części teoretycznej poniżej, wyżej wspomniane inicjatywy publikacyjne oparte na gatunku opisu przypadku zostaną omówione.

\section{Gatunkowe zróżnicowanie medycznych opisów przypadków}

Modelowy wzorzec tradycyjnego opisu przypadku dzieli się na: Wprowadzenie (ang. Introduction), w którym znajduje się rys historyczny oraz zarysowanie problemu i jego skali, informacja o historii danej choroby i częstotliwości jej występowania, a także krótki przegląd literatury i wcześniejszych badań, jak również uzasadnienie podjęcia problemu - cel pracy; Opis przypadku (ang. Case report), wielopłaszczyznowo omawiający wywiad lekarski, historię choroby i wywiad rodzinny, wieloaspektową diagnostykę, leczenie i rehabilitację; Dyskusjęl Omówieniel Komentarz (ang. Discussion), zawierającą porównanie opisywanego przypadku z aktualnym stanem wiedzy, interpretację wyników, ocenę unikalności przypadku; oraz Wnioski (ang. Conclusion), które przedstawiają krótkie podsumowanie, własne doświadczenia $\mathrm{w}$ ramach opisywanego przypadku i możliwe rekomendacje, związane zarówno z procesem diagnostycznoleczniczym, jak i z koniecznością podjęcia dalszych badań w zakresie opisywanego zjawiska (H. Cohen 2006: 1888-1890). Ten model został także zastosowany do analizy retorycznej materiału badawczego, zaprezentowanego w części empirycznej niniejszej pracy.

Jedną z pierwszych zmodyfikowanych wersji badanego gatunku był opis oparty na faktach (ang. evidence-based case report), który pojawił się w 1998 roku w czasopiśmie British Medical Journal (C.A. Guimaraes 2015: 280). Celem tej odmiany jest przedstawienie jak fakty i dowody mogą być wykorzystywane na wszystkich etapach kompleksowej opieki nad pacjentem. Opisy oparte na faktach, w przeciwieństwie do tych tradycyjnych, nie zawierają retrospekcyjnego przedstawienia nowej choroby lub jej przejawu, a ich założeniem jest raczej zilustrowanie postępów w leczeniu lub odpowiedzi na nie oraz porównanie tego z dostępną wiedzą (A. Jones-Harris 2003: 75). A. Jones-Harris (2003: 75) wyróżnia pięć elementów, które powinny znaleźć się w takim opisie: 1. postawienie pytania klinicznego; 2. szukanie dowodu i potwierdzenia; 3. krytyczna ocena dowodów według ich ważności i znaczenia; 4. podjęcie decyzji, biorąc pod uwagę dowody i doświadczenie kliniczne; oraz 5. postępy w leczeniu i odpowiedź na nie. Na początku każdego opisu pojawia się krótka charakterystyka pacjenta, a następnie prezentacja faktów i dowodów w podsekcjach: Search, zawierająca punkty 1-2, wyszczególnione powyżej; Evidence (punkty 3-4) oraz Outcome (5). 
Następna odmiana to opis łączący wyżej wymienioną wersję raportu opartą na faktach $\mathrm{z}$ bardziej subiektywnymi relacjami lekarza i pacjenta (ang. integrated narrative and evidence based case report), publikowany na łamach czasopisma British Medical Journal. Przesłaniem stojącym za tą odmianą jest przekonanie iż medycyna oparta na faktach (ang. evidence-based medicine) może czerpać wiedzę również z relacji pacjentów. Strukturalnie, opisy przypadku tego typu łączą krótkie teksty lub przeplatające się wypowiedzi autorstwa lekarzy i pacjentów, często tworzące swego rodzaju wymianę zdań, wzbogacone innymi informacjami dotyczącymi badanego problemu i poszukiwania dostępnych rozwiązań, podanymi w skrótowej formie podpunktów. Jak zauważają autorzy poszczególnych artykułów, połączenie tych dwóch perspektyw pozwala czytelnikom na prześledzenie procesu dotyczącego wyboru leczenia w kontekście konkretnych relacji lekarz-pacjent. „Kiedy opowieści lekarza i pacjenta spotykają się, medycyna staje się profesją uzdrawiania dla obydwu stron" (A.W. Frank 1998 w S. Reis et al. 2008: 1019). Pokazuje również, że ,lekarze nie są biernymi nośnikami terapeutycznych rozwiązań" (zob. S. Reis et al. 2008: 1019) i, że subiektywna percepcja lekarza może być również czynnikiem decydującym.

Kolejną odmianą gatunku jest tzw. wersja interaktywna (ang. interactive case report) zainicjowana również przez British Medical Journal w roku 2003 (R. Smith 2008a, 2008b; M. Murawska 2014). Tutaj pojedynczy opis przypadku miał formę serii raportów poświęconych jednemu tematowi, składających się z Prezentacji przypadku (ang. Case presentation), przedstawiającej dany przypadek choroby i zapraszającej czytelników do dyskusji, Postępów przypadku (ang. Case progress), opisujących przebieg leczenia, oraz Rezultatów leczenia (ang. Case outcome), podsumowujących wyniki podjętej terapii a także zawierających dyskusję i wskazania do dalszych badań. Innowacyjność tej odmiany, jej tzw. interaktywność, miała podwójny charakter - możliwość dla czytelników komentowania na bieżąco prezentowanych kwestii oraz sekcja Perspektywa pacjenta (ang. Patient's perspective), pojawiająca się w ostatniej części, gdzie sam pacjent mógł wypowiedzieć się o swoich doświadczeniach z chorobą i leczeniem, w formie pierwszoosobowej narracji.

Należy zauważyć, że ten sam głos pacjenta w poprzedniej odmianie włączany był w główną część tekstu, a co za tym idzie, akcenty rozłożone były nieco inaczej. Dodatkowo, w odmianie interaktywnej, tekst ten mógł być pisany przez samego pacjenta, w kooperacji z lekarzem lub, rzadziej, przez samego lekarza. Interaktywne opisy przypadku były więc serią mniejszych opowieści autorstwa lekarzy, czytelników i pacjentów, dodatkowo o charakterze dynamicznym, gdyż dany wątek rozwijał się na przestrzeni trzech tekstów. Można powiedzieć zatem, że interaktywna odmiana umożliwiła społeczności medycznej i innym czytelnikom ,podzielenie się kwestiami dotyczącymi komunikacji z innych perspektyw, wzbogaconymi o wkład pacjenta (E. Peile 2003: 1136; cf. S. Biswas). Projekt został po pewnym czasie zakończony, głównie ze względu na jego czasochłonny charakter, jednak sama idea interaktywności w formie komentarzy czytelników i włączania perspektywy pacjenta jest nadal rekomendowana przez redaktorów fachowych czasopism medycznych.

Innym przykładem są tu tzw. edukacyjne serie artykułów bazujących na opisie przypadku, odnoszące się zatem do jego głównej roli rozpowszechniania informacji na temat szeroko pojętych nowych jednostek chorobowych. W tego typu tekstach prezen- 
towane są „scenariusze” (B. Pregerson 2014) wyjątkowo trudnych sytuacji pod kątem diagnostyki i leczenia, swego rodzaju „wyzwania”, nawiązując do nazwy jednej z takich serii - "Case Challenges" (Medscape). Inne przykłady tego typu przedsięwzięć to m.in. "Lesson of the Week" or "Drug Points" (British Medical Journal), "Interpretation Corner" (European Radiology), "Pulmonary and Critical Care Pearls" oraz "Teaching Case of the Month" (Respiratory Care).

Ostatnia odmiana badanego gatunku to tzw. "Patient Experience case studies", opracowane w ramach projektu "Patient First Review", zrealizowanego w prowincji Saskatchewan w Kanadzie. Celem przedsięwzięcia było zbadanie poziomu jakości usług medycznych z perspektywy pacjenta, a same studia przypadków miały uzupełnić raport $\mathrm{z}$ tego projektu. Jeśli chodzi o ich strukturę, były one relatywnie złożone, składające się z następujących części: Wstęp (ang. Introduction, wprowadzenie do danego przypadku i aspekty istotne dla sprawy), Opowieść pacjenta (ang. Patient's story, narracja w 3 osobie, jednak opis bardzo szczegółowy i obierający perspektywę pacjenta), Dyskusja przypadku (ang. Case discussion, jak dany problem został rozwiązany i jak to wpłynęło na jakość życia pacjenta), Rozwiazania w praktyce (ang. Leading practices, dostępne i sugerowane rozwiązania), oraz Historia pacjenta opowiedziana ponownie (ang. Patient's story retold, perspektywa lekarza).

Ważnym w kontekście niniejszej pracy jest inny charakter opowieści pacjenta i lekarza, które różniły się zastosowanym słownictwem, perspektywą piszącego oraz rozłożeniem akcentów komunikacyjnych (samo porównanie nie było celem projektu na żadnym etapie). Podczas gdy narracja pacjenta była dłuższa oraz skupiała się raczej na doświadczeniu choroby i jej wpływu na jego życie codzienne, tekst lekarza, choć nie bez uwzględnienia zdania leczonego, koncentrował się na procedurach medycznych oraz samym leczeniu i często pomijał problematyczne kwestie podnoszone przez leczonego. Należy zauważyć również, że o ile każdy z przygotowanych studiów w ramach serii nosił imię konkretnego pacjenta, np. "Mathew's story", "Kate's story", często stanowił on kompilację kilku podobnych przypadków. Wybrane opisy oraz pełna dokumentacja dotycząca projektu dostępna jest na stronie: http:// www.health.gov.sk.ca/ patient-first-review.

\section{Przegląd literatury oraz wspólczesny stan badań}

Anglojęzyczne badania dotyczące szeroko pojętego opisywania przypadków, porównywalnie mniej liczne niż innych gatunków medycznych, podejmowały różnoraką tematykę. $\mathrm{Z}$ jednej strony, istnieją badania dokumentujące rozwój tego gatunku tle historycznym, biorące pod uwagę zmieniające się prądy naukowe. W tego typu badaniach, interesującą dla autorów jest ewolucja obrazu pacjenta i postrzegania choroby, jednak bez formalnej analizy językowej (np. S.J. Reiser 1991; H. Nowell-Smith 1995; B. Hurwitz 2006). Współczesne kierunki rozwoju gatunku zostały z kolei opisane m.in. przez D. Pierson (2009) oraz T. Nissen i R. Wynn (2014). Do tej grupy badań można też zaliczyć jedno z najbardziej wyczerpujących źródeł dotyczących opisu przypadku i jego odmian w dyskursie medycznym - książkę K. Hunter Doctors' stories. The narrative structure of medical knowledge (1991), która szczegółowo przedstawia konwencje tworzenia, strukturę oraz funkcje poszczególnych odmian tego mikro-gatunku. Z drugiej strony, w badaniach językowych obierane są różne podejścia i metody analizy: 1) 
badania ilościowe cech semantycznych i składniowych oraz ich zadań (E. RowleyJolivet 2007; B. Méndez-Cendón 2009; P. Mungra/ T. Canziani 2013) czy metadyskursu (D.E. Adams Smith 1984; F. Salager-Meyer 2001); 2) studia diachroniczne tekstowych odniesień do pacjenta w opisach diagnozy i leczenia (I. Taavitsainen/ P. Pahta 2000) oraz praktyk związanych z tytułowaniem artykułów czy ich autorstwem (F. Salager-Meyer/ M. Alcaraz Ariza 2013); 3) podejście gramatyki systemowo-funkcjonalnej przy porównaniu opisów przypadku z tekstem literackim (G. Francis/ A. Kramer-Dahl 2004); 4) perspektywa kulturowa (E. Coker 2003); oraz 5) analiza multimodalna gatunku z psychiatrii (C. Berkenkotter 2008). Część badań odnosi się też do współczesnych medycznych opisów przypadku i ich funkcji z perspektywy pedagogicznej, opowiadając się albo za lub przeciw jego zastosowaniu (T. Treasure 1995; J. Pettinari 1998; J.P. Vandenbroucke 2001; J. Neely et al. 2008; G. Garzone 2011). Istnieją również badania odmian pokrewnych, tj. historia choroby/ zapis czy notatka, odnoszących się do określonych przypadków (np. J.F. Burnum 1989; R. Charon 1992; W.J. Donnelly 1992, 1996; R.J. Sobel 2000; S. Sarangi/ L. Brookes-Howell 2006; E.L. Siegler 2010) czy też prezentacje przypadków, odbywające się podczas obchodu w szpitalu (np. R. Anspach 1988; L. Lingard et al. 2003).

Według wiedzy autorek niniejszej pracy, w polskim piśmiennictwie nie są dostępne opracowania na temat opisów przypadków dotyczące ich struktury retorycznej, językowej, czy perspektywy pacjenta. Można wskazać jedynie na krótkie opracowania zawierające wskazówki, jak pisać modelowy opis przypadku, autorstwa K. Krzemienieckiego (2010) i P. Czapiewskiego (2015), czy też źródła bardziej ogólne, dotyczące języka medycznego (M. Ławnicka-Borońska 2013), wspominające o tym gatunku.

\section{Analiza materiału badawczego}

\subsection{Dane i metody}

Materiał badawczy podzielono na dwie części: polskojęzyczne i anglojęzyczne formy piśmiennictwa stanowiące odmiany medycznego opisu przypadku. W skład pierwszej części weszło 13 tradycyjnych opisów przypadków z czasopism w języku polskim: Otorynolaryngologia, Kardiologia Polska, Ginekologia Polska oraz Chirurgia Polska. W drugiej części uwzględniono 25 artykułów: tradycyjne opisy przypadku, opisy oparte na faktach (ang. evidence based case report), opisy łączące fakty oraz subiektywne relacje pacjenta i lekarza (ang. integrated narrative and evidence based case report), opisy interaktywne (ang. interactive case report), serię "Patient Experience case studies", listy do redakcji zawierające opisy przypadków oraz formy skrótowe (ang. medical images/ flashlights), zaczerpnięte z następujących czasopism: British Medical Journal, Otolaryngology - Head and Neck Surgery, Archives of Otolaryngology Head and Neck Surgery, Journal of Clinical Oncology, Case Reports in Dermatology oraz European Heart Journal. Wszystkie czasopisma zostały wybrane na podstawie Listy czasopism punktowanych Ministerstwa Nauki i Szkolnictwa Wyższego ze względu na wysoką liczbę punktów, co ma swoje przełożenie na prestiż danego tytułu ${ }^{1}$.

W polskim piśmiennictwie medycznym tradycyjne opisy przypadków stanowią jeden z powszechniejszych i bardziej znanych rodzajów pisarstwa opisowego dotyczące-

${ }^{1}$ http:/ / www.nauka.gov.pl/ ujednolicony-wykaz-czasopism-naukowych/ 
go przypadków, jednak odmiany, takie jak np. opisy interaktywne czy serie o charakterze edukacyjnym, nie są jeszcze obecne.

Analizę lingwistyczno-retoryczną wykonano w oparciu o wybrane wyznaczniki metadyskursu, przedstawione przez K. Nwogu (1997) oraz K. Hylanda (2011), którzy na podstawie przeprowadzonych badań wyróżnili elementy lingwistyczno-retoryczne $\mathrm{w}$ artykułach medycznych, m.in. czasy gramatyczne, strony czasownika, formy osobowe i nieosobowe czasowników, używanie odpowiednich leksemów, łązniki (ang. transition markers), znaczniki ram interpretacyjnych (ang. frame markers), znaczniki objaśniajace kod (ang. code glosses), znaczniki endoforyczne (ang. endophoric markers), znaczniki asekuracji (ang. hedges), wzmacniacze (ang. boosters), znaczniki nastawienia (ang. attitude markers), znaczniki samoprezentacji (ang. self-mentions) itp. (K. Nwogu 1997: 119-138; K. Hyland 2011: 196-212; E. Donesch-Jeżo 2013: 49-54).

\subsection{Struktura odmian gatunku}

\section{(a) Typowa konstrukcja}

Pierwszym etapem badania było przeanalizowanie struktury wybranych do materiału badawczego artykułów i wykazanie ich cech charakterystycznych. Polskojęzyczne opisy przypadku zazwyczaj miały typową formę, zgodną z kanonicznym modelem. Co więcej, wszystkie tradycyjne opisy przypadków, zarówno te polskojęzyczne, jak i anglojęzyczne, które zostały poddane analizie, zawierały charakterystyczne elementy składowe, które przedstawione są w Tabeli 1.

\begin{tabular}{|c|c|}
\hline Podsekcja & Zagadnienia \\
\hline $\begin{array}{l}\text { Wprowadzenie/ Wstęp (ang. Background/ } \\
\text { Introduction) }\end{array}$ & $\begin{array}{l}\text { 1. Tło historyczne - krótki opis wystę- } \\
\text { powania choroby i jej znaczenia w } \\
\text { świecie } \\
\text { 2. Definicja choroby/ zjawiska } \\
\text { 3. Zarys skali problemu - wskazanie na } \\
\text { znamienność opisywanego zagadnie- } \\
\text { nia } \\
\text { 4. Cel danej pracy/ opisu }\end{array}$ \\
\hline $\begin{array}{l}\text { Opis przypadku (ang. Case report/ Report } \\
\text { of the case) }\end{array}$ & $\begin{array}{l}\text { 1. Przedstawienie pacjenta } \\
\text { 2. Historia choroby pacjenta (w prze- } \\
\text { szłości) } \\
\text { 3. Wywiad rodzinny } \\
\text { 4. Stan przy przyjęciu } \\
\text { 5. Wykonane badania diagnostyczne } \\
\text { 6. Diagnoza } \\
\text { 7. Zastosowane leczenie i rehabilitacja } \\
\text { 8. Dalsze zalecenia lekarskie }\end{array}$ \\
\hline $\begin{array}{l}\text { Omówienie/ Dyskusja (Discussion/ Com- } \\
\text { ment) }\end{array}$ & $\begin{array}{l}\text { 1. Powtórzenie znamienności problemu } \\
\text { 2. Przegląd literatury } \\
\text { 3. Odwołanie do innych badań } \\
\text { 4. Wskazanie na dalszy kierunek badań } \\
\text { 5. Zalecenia oraz dalsze rekomendacje }\end{array}$ \\
\hline
\end{tabular}

Tabela 1. Elementy sktadowe i omawiane w nich zagadnienia w opisach przypadków. 
Pierwszym z elementów składowych było Wprowadzeniel Wstęp (ang. Background/ Introduction), zawierające przedstawione poniżej zagadnienia.

Tło historyczne - krótki opis wysteppowania choroby i jej znaczenia w świecie

- W ostatnich latach obserwuje się wzrost odsetka ciąż wielopłodowych zwiąanych z coraz powszechniejszym stosowaniem leków stymulujących jajeczkowanie. GP18

- Nużeniec ludzki (...) opisany zostat po raz pierwszy przez Simona i Bergera w połowie XIX wieku. OT1

- W polskim piśmiennictwie otolaryngologicznym znaleziono jedynie jeden opis zachorowania na tularemię. OT2

- These tumors are very rare in the sinonasal tract (...). In the literature; there are cases reported as fibrolipomas in the esophagus, pharynx, colon, trachea, larynx and oral cavity. JO1

- Over the past few years, paclitaxel has been used in advanced-stage and/ or metastatic angiosarcoma. DR1

Definicja choroby/ zjawiska

- Nużyca jest choroba skóry wstęująca zarówno u ludzi, jak i zwierząt. OT1

- Marjolin's ulcer arising is a malignant, ulcerating neoplasm occurring in cicatrical tissue. HN3

Zarys skali problemu - wskazanie na znamienność opisywanego zagadnienia

- Rak żołądka jest jednym z najczęściej występujących nowotworów wśród mieszkańców krajów wysokorozwiniętych. $\mathrm{CH} 2$

- Bronchogenic cysts are rare congenital anomalies that are usually located in the mediastinum or lung parenchyma. HN1

Cel danej pracy/ opisu

- W niniejszym artykule autorzy przedstawili przypadek chorej-świadka Jehowy - operowanej z powodu raka żoładka. $\mathrm{CH} 2$

- Celem pracy była ocena polimorfizmów genu GDF-9 u pacjentki ze staba odpowiedzia na dwukrotna kontrolowana hiperstymulacje jajników w programie zapłodnienia pozaustrojowego. GP1

- We report a case of squamous cell carcinoma of the scalp arising 65 years after a split-thickness skin graft of a full-thickness burn. HN3

- This article presents a patient with nasal septal fibrolipoma, and to the knowledge of the researchers, it is the first reported nasal septal case in the literature. JO1

Kolejną część, stałą w każdym artykule, stanowił Opis przypadku (ang. Case report/ Report of the case). W niektórych pracach, szczególnie anglojęzycznych, był on początkowym elementem, pełniąc jednocześnie rolę wstępu i wprowadzenia. Opis przypadku zawierał wypunktowane poniżej kwestie, które obecne były w mniejszym lub większym stopniu, w każdym analizowanym artykule.

$\underline{\text { Przedstawienie pacjenta }}$ 
- Do Poradni Genetycznej zgtosita się 27-letnia pierwiastka w 30 tygodni ciaży z powodu podejrzenia wodogłowia oraz wewnątrzmacicznego zahamowania wzrostu płodu. GP10

- Chora w wieku 70 lat skierowano do Pracowni Echokardiografii w celu wykonania rutynowego przezklatkowego badania echokardiograficznego. KR1

- A 17-year-old Asian Man presented with painless bilateral reduction in his vision. CR1

- A 72-year-old woman with a history of a fire burn to her left trunk and center of the scalp at age 7 was referred to our clinic with a 4-month history of an ulcerative lesion arising within a scalp burn. $\mathrm{HN} 3$

Historia choroby pacjenta (w przeszłości)

- Od 20 lat byta ona leczona z powodu nadciśnienia tętniczego. KR1

- Dziecko miało stały kontakt ze zwierzętami domowymi (króliki, pies, kot). Uprzednie leczenie ambulatoryjne - nieskuteczne. OT2

- The patient had no history of systemic disease or trauma. CR1

- She has previously been evaluated and treated for rhinitis and thinosinusitis. $\mathrm{AO} 1$

Wywiad rodzinny

- Pacjentka leczyta się na niedoczynność tarczycy; $w$ rodzinie u chorej nie występowaty wcześniej choroby onkologiczne. $\mathrm{CH} 2$

- His medical family history had revealed nothing abnormal. JO1

Stan przy przyjecciu

- Chora została przyjęta do oddziatu w stanie ogólnym dobrym, stabilnym, w petnym kontakcie słowno-logicznym. $\mathrm{CH} 2$

Wykonane badania diagnostyczne

- W badaniu laryngologicznym nie znaleziono zmian patologicznych nosa, gardta, krtani, ani uszu. OT1

- An incisional biopsy was performed on the mass under local anesthesia. JO1 Diagnoza

- Desensybilizacje przysadki potwierdziło w badanach hormonalnych $w$ surowicy krwi. GP1

- Ostatecznie echokardiograficznie rozpoznano przerwanie ciagtości łuku aorty typu "B" z okolobłoniastym ubytkiem międzykomorowym i hipoplazja tuku aorty. KR0

- The patient was diagnosed with CNV in both eyes and he underwent bilateral intravitreal injections of ranibizumab five times over six months. CR1

- The final histopatologic examination of the excised mass confirmed the preoperative diagnosis of fibrolipoma. $\mathrm{JO} 1$

Zastosowane leczenie i rehabilitacja

- Po przyjęciu $i$ wykonaniu badań laboratoryjnych wdrożono postępowanie zachowawcze, leczenie tokolityczne, antybiotykoterapię GP18

- The patient underwent 8x10-cm-wide local excision with 2-cm margins of the scalp SCCA. HN3

Dalsze zalecenia lekarskie

- (Pacjentka) została skierowana na dalsze leczenie chemioterapeutyczne. $\mathrm{CH} 2$ 
- Po zabiegu pacjent zostal wypisany do domu w stanie ogólnym dobrym. OT1

- The patient has since continued with crizotinib treatment, with no evidence of extracranial tumor progression for 6 months. $\mathrm{CO} 2$

- The patient was discharged from the hospital uneventfully 5 days postoperatively. HN3

Ostatnią podsekcję w każdym z opisów stanowiło Omówieniel Dyskusja (Discussion/ Comment). Była to najobszerniejsza i najbardziej opisowa część każdego opisu przypadku. W zależności od czasopisma, poruszane zagadnienia pojawiały się w różnej kolejności.

Powtórzenie znamienności problemu

- Prawostronna lokalizacja śluzaków serca jest bardzo rzadka, szczególnie guzów zlokalizowanych na zastawce trójdzielnej (3). KR1

- Nużeniec ludzki barwy białej lub żóltej (...) jest rozpowszechniony na całym świecie. OT1

- The peak incidence is in the fifth and sixth decades of life, and they are rare under the age of 20 years. JO1

- These studies are necessary to determine the potential presence of a primary tumor in addition to documenting additional metastases. AO2

Przeglad literatury

- W literaturze opisywane sa przypadki rodzinnego wystepowania tej choroby. OT3

- Our literature review showed that a large percentage of previous reports have involved female patients aged 8 to 60 years. $\mathrm{HN} 2$

Odwołanie do innych badań

- Stamenković i wsp. opisali przypadek 67-letniej chorej z krwawieniem z górnego odcinka przewodu pokarmowego spowodowanym wrzodem żoładka $i$ mięśniakiem gładkokomórkowym żoładka. $\mathrm{CH} 2$

- Dolenc-Voljć i wsp. wskazuja na niewielki udziat w patogenezie zapalenia okołowargowego skóry roztoczy grupy Demodex. OT1

- In 2006, SaMillan Ruiz et al reported 2 cases of patent foramen cecum veins that were identified by digital subtraction angiography in 2 women. AO1

- The thyroglottic ligament was first described by Tucker and Smith in 1962. $\mathrm{AO} 3$

Wskazanie na dalszy kierunek badań

- Further investigation is necessary to determine the possible correlation between the two disorders and investigate the precise mechanism behind these diseases. CR1

Oprócz powyższych elementów, w opisach przypadków obecne były także wyrażenia przedstawiające zalecenia oraz dalsze rekomendacje:

- W celu poprawy rokowania w przypadku porodu odroczonego sugeruje sie stosowanie wielorakich dziatań jak reżim tóżkowy (...) GP18

- There are no reports of recurrence of tonsillar lipomas; hence, we recommend tonsillectomy with excision of the mass as definitive treatment. HN2

W dyskusji artykułach anglojęzycznych wskazuje się także lukę w badaniach lub konieczność uzupełnienia danej wiedzy, stosując często formy przeczące i przymiotni- 
ki o negatywnym znaczeniu. Element identyfikacji niszy w badaniach nie występuje w polskojęzycznych opisach przypadków. Należy też podkreślić iż o ile tendencje te są widoczne w standardowych artykułach medycznych, to w opisach przypadków nie jest do końca możliwe precyzyjne wskazanie luki w badaniach, ze względu na rzadkość lub nawet nieobecność danych zjawisk wśród pacjentów.

- However, development in the nasal septum has not yet to be reported. JO1

\section{(b) Inne odsłony struktury}

Oprócz tradycyjnych opisów przypadków, w zależności od czasopisma i jego profilu, obecne były także inne odsłony. Pierwszym przykładem jest opis oparty na faktach (ang. evidence-based case report). Jak wspomniano w części teoretycznej, odmiana ta dzieli się na trzy główne podsekcje (Search, Evidence, Outcome), poprzedzone krótką charakterystyką pacjenta:

\section{Charakterystyka pacjenta}

- Mrs V was a 66 year old woman who said she had had a non>productive cough almost daily for 20 years. EB1

- My patient, an elderly woman, had been admitted to the trauma ward via the accident and emergency department on the previous day because she had sus> tained a trochanteric fracture of the left hip after a simple fall at home. EB2

Search (postawienie pytania klinicznego, przegląd literatury, szukanie dowodu)

- An initial search of Medline for randomised trials showed that there had been 48 studies in the past three years alone. Given the time available, I limited my search to systematic reviews of randomised trials. Where my questions were not answered by these reviews, I referred to independent reviews and clinical guidelines. EB2

- My favourite ambulatory care text, Primary Care Medicine listed 20 possible causes of chronic cough. EB1

Evidence (analiza dowodów, podjęcie decyzji o leczeniu)

- Since access to $\mathrm{pH}$ monitoring is difficult and fairly costly I decided to treat her reflux with simple measures. I discussed the options with her. She was not worried that the reflux indicated serious disease but was irritated by the cough. EB1

Outcome (postępy w leczeniu i odpowiedź na nie)

- My patient made an uneventful recovery from surgery. Nine days later she was discharged home with the support of the hospital at home services within the community. EB2

Kolejnym przykładem są dwujęzyczne opisy przypadków, publikowane w Chirurgii Polskiej, które posiadają konwencjonalną strukturę podziału na sekcje, jednak ułożone są kolumnowo i zawierają opis danego przypadku w języku polskim oraz jego tłumaczenie na język angielski. Jako przykład mogą posłużyć następujące fragmenty (CH5):

- U chorej stwierdzano równocześnie dodatni wywiad rodzinny: matka chorej zmarta z powodu raka jelita grubego $w$ 49. rż., ojciec zmart z powodu raka pluca $w$ 47. rż., siostra $w$ wieku 36 lat choruje na raka jelita grubego i raka endometrium. 
- The patient's mother died from colorectal cancer at the age of 49, the patient's father died from lung cancer at the age of 47, the patient's sister, aged 36, is suffering from colorectal cancer and endometrial cancer.

„Studium przypadku” (ang. "Clinical vignette”) pojawia się obok tradycyjnych opisów przypadków w czasopiśmie Kardiologia Polska. Polega ono jedynie na przedstawieniu przypadku - pacjenta, historii choroby, wykonanych badań, zastosowanego leczenia oraz wyników po nim. Nie występuje tu zatem Wstęp, Przeglad literatury, Dyskusja, Wnioski, itp, nie jest też podzielone na podsekcje. Studium przypadku rozmieszczone jest na jednej stronie formatu A4.

Skrótowe opisy przypadku pojawiają się także w Otolaryngology - Head and Neck Surgery, w formie o nazwie "Clinical photograph". Podobnie jak w przypadku powyżej, skrótowe opisy zawierają tylko informacje dotyczące występowania danej choroby, diagnostyki, leczenia i rehabilitacji. Jednakże w odróżnieniu od "Clinical vignette", "Clinical photograph" zawiera także Dyskusję i Wnioski, chociaż tekst jest ciągły, bez podziału na poszczególne sekcje. Podobny format mają opisy publikowane w European Heart Journal, zwane "Cardiovascular flashlights". Są one rozmieszczone na jednej stronie i zawierają najważniejsze informacje o przypadku oraz krótką dyskusję. Można to zatem uznać tylko za zarysowanie danego problemu i zwrócenie uwagi na ważne kwestie.

W Journal of Clinical Oncology publikowany jest rozdział "Diagnosis in oncology". Artykuły w nim zawarte stanowią swoisty typ opisu przypadku, nie zawierają jednak wstępu, rozpoczynając się od razu od zaprezentowania pacjenta. Omówienie oraz Przegląd literatury znajdują się po krótkim opisie przypadku. W tym miejscu warto zauważyć, iż wiele anglojęzycznych opisów nie zawiera wstępu, tha historycznego, przeglądu literatury i wskazania celu pracy oraz zarysowania problemu na początku pracy - elementy te pojawiają się po przedstawieniu przypadku i są dość rozwinięte.

Za ważny $\mathrm{i}$ wartościowy $\mathrm{z}$ dydaktycznego punktu widzenia, analogicznie do wspomnianej serii "Case Challenges", uznać można cykl artykułów publikowanych w Archives of Otolaryngology - Head and Neck Surgery - pod nazwą "Clinical problem solving". Dotyczy on dwóch dziedzin: patologii i radiologii. Każdy tekst składa się tu z dwóch części. Pierwsza to Quiz case, która zawiera krótki opis przypadku: pacjenta, historię choroby, badania i otrzymane wyniki. Zakończony jest pytaniem „Jaka jest twoja diagnoza?". W niektórych quizach jest również podany odsyłacz do filmu wideo. Część druga to Diagnosis, która rozpoczyna się podaniem prawidłowej diagnozy, po czym następuje opis choroby, definicje, częstotliwość występowania, sposoby leczenia, przegląd literatury oraz odwołanie się do innych badań - czyli, innymi słowy, podsekcja Omówienie.

W niektórych czasopismach nie istnieją jednak specjalnie wydzielone rubryki lub rozdziały dla publikacji opisów przypadków. Są one umieszczane wtedy w „Listach do redakcji" (ang. "Letter to the editor"). Przykładem może być Journal of Clinical Oncology. Taki artykuł nie jest podzielony na podsekcje, jednak zawiera standardowe elementy tradycyjnego opisu przypadku - od zarysowania problemu i tła historycznego, poprzez opis choroby, kończąc na szeroko rozumianej dyskusji. 


\subsection{Patient's perspective - nowe spojrzenie na przypadek}

W wybranych artykułach anglojęzycznych, szczególnie w interaktywnej odmianie, pojawiała się część zawierająca wypowiedź pacjenta - Patient's perspective - będąca pierwszo-osobową narracją. Element ten był niedostępny w polskojęzycznych opisach. $\mathrm{W}$ piśmiennictwie anglojęzycznym interaktywna wersja zawiera krótki opis przypadku i wykonanych badań, a następnie zarówno komentarze innych specjalistów jak i komentarz pacjenta. Ta część może być zilustrowana następującymi fragmentami:

- I hope my case will be helpful for other patients who suffer from a disease like me. CR1

Jako przykład komentarzy innych specjalistów warto podać:

- "Sitting things was not a viable option in Ruth's case because of the risk of rupture" (Commentary: Vascular surgeon) BM4

Dodatkowo warto wspomnieć o tzw. integrated narrative and evidence based case report, w którym perspektywa pacjenta stanowi główną część opisu. Poprzedzona jest wstępem, zarysowaniem problemu wraz z tłem historycznym, przeglądem literatury, a po niej następuje dyskusja na temat przypadku. Sam przypadek zostaje przedstawiony w formie przeplatających się wypowiedzi lekarza i pacjenta, którzy wyrażają swoje odczucia. Świadczyć może o tym następujący fragment:

- Patient: "I feel quite depressed now that I'll eventually, once again, become the same week person I was at the begginign of my life... and I simply do not want and will not accept this". BM1

- Doctor: "I respect that personal health believe model, which is definitely different from my own. She wants to be giuded by her inner feelings rather than by fear, and she finally decides no to warfarin, yes to atenolol, and yes to aspirine”. BM1

Perspektywa pacjenta jest szczególnie widoczna w serii "Patient Experience case studies" w ramach projektu "Patient First Review", który omówiony był w części teoretycznej. Każde studium zawiera relację pacjenta w mowie zależnej (np. "Mathew's story"), opisującą przypadek z uwzględnieniem odczuć i obaw samego pacjenta, oraz tę samą relację ponownie, podkreślającą perspektywę lekarza (np. "Mathew's story retold", zależnie od imienia konkretnego pacjenta).

- Several month ago, Matthew started having slight pain in his stomach. He had a visit schledued in a week with the family physician in their home town, an hour outside Regina, so Jeffrey asked Matthew if he felt it could wait until then. Matthew felt that it could. PE1

- Unfortunately, the cilculatory problems that were causing the numbness in Walter's foot continued to worsen. While waiting for calls about his next test or appointment, Walter continued to struggle with depression, spent much of his time watching television, and ate poorly. PE2

\section{Analiza lingwistyczno-retoryczna}

Drugim elementem badania była analiza lingwistyczno-retoryczna, która pozwoliła na wykazanie tendencji i charakterystycznych cech w metadyskursie medycznym w opisywaniu przypadków. 
W odniesieniu do cech gramatycznych, wskazać można szereg tendencji. Po pierwsze, w artykułach przeważają formy czasu przeszłego, stosowane do opisu przypadku, wykonanych badań, zastosowanego leczenia itp. Formy czasu teraźniejszego występują we wskazaniu aktualności badań i ogólnie znanych faktów:

- Ryzyko nowotworzenia w catym okresie życia wynosi 50-80\% dla raka jelita grubego, 40-60\% dla raka endometrium, 11-19\% dla raka żołądka, 9-12\% dla raka jajnika (2). CH5

- Keratoconus is an idiopathic, progressive, noninflammatory ectasia of the lower central cornea, which possibly results from a disorder originating in the corneal epithelial basement membrane. CR1

$\mathrm{W}$ anglojęzycznych opisach przypadków badania i dotychczasowe osiągnięcia oraz kontynuacja leczenia pacjenta opisane są z użyciem czasu Present Perfect:

- It has been associated with a variety of ocular disorders, including retintis pigmentosa. CR1

Dostrzec możemy także formy bezosobowe, które służą do silniejszego podkreślenia wykonywanej czynności, bez skupienia uwagi na pacjencie lub badaczach:

- W artykule skupiono się na omówieniu prawnych aspektów zwiąanych z decyzja chorego do samostanowienia o nieprzetaczaniu krwi i jej składników. $\mathrm{CH} 2$

Formy osobowe pojawiają się w odniesieniu do pacjenta, opisując jego osobę, objawy, samopoczucie:

- W wywiadzie zglaszala $w$ ciagu ostatniego miesiąca kilkukrotne incydenty wymiotów. W ciagu ostatniego miesiąca schudta pięć kilogramów. $\mathrm{CH} 2$

- She was in average health for someone of 82 and had a medical history that included hypertension, a myocardial infarction (three years pres viously), and a fractured wrist (eight years before). EB1

W opisach przypadków dominują wyrażenia w stronie biernej, które podobnie jak formy bezosobowe, podkreślają wykonane czynności, oddalając uwagę od wykonawcy:

- Elective left tonsillectomy with excision of the tonsillar mass were performed. HN2

W polskojęzycznych opisach przypadków także możemy zauważyć tendencję do stosowania form bezczasownikowych, które pozwalają przekazanie informacji w sposób zwięzły, bez nacechownania emocjonalnego. Kompresja ta jest jedną z cech stylu naukowego.

- $\quad$ Badanie podmiotowe, wywiad środowiskowy i rodzinny bez znaczenia klinicznego. GP10

- Czynność serca miarowa 80/ minute, tony serca głośne. CH2

Formy przeczące i przymiotniki o znaczeniu negatywnym stosowane są do wskazania luki w badaniach, braku danego czynnika lub odchylenia od normy.

- There was no history of tobacco or alcohol use or extensive sun exposure. HN3

- $\quad$ The exact etiology of laryngoceles is unknown. JO3

- Przebieg pooperacyjny byt niepowikłany. CH2

- $\quad$ The underlying calvarium appeared irregular. HN3 
Kolejnym z elementów wykonanej analizy lingwistyczno-retorycznej jest analiza metadyskursu, który podzielić można na interaktywny (tekstowy), umożliwiający „prowadzenie” czytelnika przez tekst, oraz interakcyjny, pomagający w ukazaniu stanowiska dotyczącego prezentowanej informacji i stanowiska czytelników oraz kontrolowanie poziomu osobistego zaangażowania, dodatkowo regulując odpowiednio siłę prezentacji informacji.

Wskaźnikami dyskursu interaktywnego są łaczniki (ang. transition markers), które pomagają czytelnikowi interpretować związki pomiędzy etapami argumentacji i koncepcjami autora dyskursu, zapewniając tym samym spójność tekstu. Są to również najczęściej pojawiające się elementy retoryczne opisów. Kolejnymi wskaźnikami są znaczniki ram interpretacyjnych (ang. frame markers), zapewniające schematyczną strukturę poprzez przedstawienie kolejności prezentacji oraz sekwencję informacji w tekście; znaczniki objaśniające kod (ang. code glosses), pomagające przeformułować informacje w celu ułatwienia jej zrozumienia i interpretacji przez czytelników; oraz znaczniki endoforyczne (ang. endophoric markers), odwołujące czytelników do innych części tekstu.

Wskaźnikami dyskursu interakcyjnego są szczególnie znaczniki asekuracji (ang. hedges), które występują w opisach przypadków najczęściej - na równi z łącznikami (ang. transition markers), i umożliwiają zmniejszenie siły prezentacji oraz otwarcie na dialog z odbiorcami. Kolejnymi wskaźnikami są wzmacniacze (ang. boosters), pozwalające zwiększyć pewność prezentowanego zagadnienia, zamykając jednak możliwość dialogu z odbiorcami; znaczniki nastawienia (ang. attitude markers), wskazujące na stosunek autora do informacji; oraz znaczniki samoprezentacji (ang. self-mentions), określające stanowisko autora w tekście (E. Donesch-Jeżo 2013: 49-54).

Tabela 2 poniżej zawiera wszystkie wymienione znaczniki metadyskursu wraz z przykładami występowania w analizowanych opisach przypadków.

\begin{tabular}{|c|c|c|c|}
\hline $\begin{array}{l}\text { Wskaźniki } \\
\text { dyskursu }\end{array}$ & $\begin{array}{c}\text { Artykuły } \\
\text { polskojęzyczne }\end{array}$ & $\begin{array}{c}\text { Artykuly } \\
\text { anglojęzyczne }\end{array}$ & $\begin{array}{c}\text { Przykłady } \\
\text { z materiału badawczego }\end{array}$ \\
\hline \multicolumn{4}{|c|}{ INTERAKTYWNY DYSKURS } \\
\hline $\begin{array}{l}\text { Lączniki (tran- } \\
\text { sition markers) }\end{array}$ & $\begin{array}{l}\text { also, although, } \\
\text { as ale, dalszy, na } \\
\text { podstawie, po- } \\
\text { dobnie, ponie- } \\
\text { waż, więc }\end{array}$ & $\begin{array}{l}\text { also, although, } \\
\text { as a result, } \\
\text { because, be- } \\
\text { sides, but, even } \\
\text { though, fur- } \\
\text { thermore, how- } \\
\text { ever, in addi- } \\
\text { tion, in con- } \\
\text { trast, moreo- } \\
\text { ver, neverthe- } \\
\text { less, nonethe- } \\
\text { less, on the } \\
\text { other hand, } \\
\text { since, so, there- } \\
\text { fore, thus, } \\
\text { while, yet }\end{array}$ & $\begin{array}{l}\text { Na podstawie powyższych danych } \\
\text { wysunięto podejrzenie dziedziczne- } \\
\text { go, niezwiazanego z polipowatościa } \\
\text { raka jelita grubego. CH5 } \\
\text { Moreover, the possibility of direct } \\
\text { extension from adjacent SCC of the } \\
\text { larynx contributes to the diagnostic } \\
\text { difficulty. JO2 }\end{array}$ \\
\hline Znaczniki ram & cel, celem, naj- & in brief, in & In brief, a lateral thyrotomy with- \\
\hline
\end{tabular}




\begin{tabular}{|c|c|c|c|}
\hline $\begin{array}{l}\text { asekuracyjnych } \\
\text { (frame mar- } \\
\text { kers) }\end{array}$ & pierw, nastepnie & $\begin{array}{l}\text { conclusion, in } \\
\text { this context, } \\
\text { now, overall, } \\
\text { subsequently }\end{array}$ & $\begin{array}{l}\text { out tracheostomy was chosen to } \\
\text { resect the laryngocele. JO3 }\end{array}$ \\
\hline $\begin{array}{l}\text { Znaczniki obja- } \\
\text { śniające kod } \\
\text { (code glosses) }\end{array}$ & $\begin{array}{l}\text { co stanowi, pole- } \\
\text { ga na tym, to } \\
\text { oznacza, } \\
\text { szczególności }\end{array}$ & $\begin{array}{l}\text { as illustrated, } \\
\text { especially, } \\
\text { indeed, known } \\
\text { as, or, that is }\end{array}$ & $\begin{array}{l}\text { Zjawisko polega na tym, że zwięk- } \\
\text { sza się liczba powtarzalnych se- } \\
\text { kwencji nukleotydów jako wynik } \\
\text { nieprawidłowej replikacji DNA w } \\
\text { komórce. CH5 } \\
\text { As illustrated in this case, a change } \\
\text { symptoms during the ascent and } \\
\text { descent of air travel can potentially } \\
\text { support the physician's diagnostic } \\
\text { suspicion of a laryngocele. JO3 }\end{array}$ \\
\hline $\begin{array}{l}\text { Znaczniki endo- } \\
\text { foryczne (en- } \\
\text { dophoris mar- } \\
\text { kers) }\end{array}$ & $\begin{array}{l}\text { rycina } X \text {, tabela } \\
X\end{array}$ & $\begin{array}{l}\text { figure } X \text {, table } \\
X\end{array}$ & $\begin{array}{l}\text { U chorej wykonano badanie tomo- } \\
\text { grafii komputerowej brzucha } i \\
\text { miednicy, w którym stwierdzono } \\
\text { pogrubienie przedniej ściany żo- } \\
\text { tądka w okolicy odźwiernika (ryc. } \\
\text { 1). CH2 } \\
\text { Corneal topography of his left eye } \\
\text { showed irregular astigmatism (...) } \\
\text { (Figure } 3 \text { B). CR1 } \\
\text { Only } 28 \text { articles were accessed, } \\
\text { totalling } 31 \text { cases, which are sum- } \\
\text { marized in table } 1 . \text { DR3 }\end{array}$ \\
\hline \multicolumn{4}{|c|}{\begin{tabular}{|l} 
INTERAKCYJNY DYSKURS \\
\end{tabular}} \\
\hline $\begin{array}{l}\text { Znaczniki ase- } \\
\text { kuracji (hedges) }\end{array}$ & $\begin{array}{l}\text { czasami, często, } \\
\text { głównie, może, } \\
\text { możliwy, mógtby, } \\
\text { około, powinien, } \\
\text { prawdopodobnie, } \\
\text { prawie, przyjąć, } \\
\text { założyć }\end{array}$ & $\begin{array}{l}\text { almost, approx- } \\
\text { imately, could, } \\
\text { could not, feel, } \\
\text { felt, generally, } \\
\text { in most cases, } \\
\text { in our point of } \\
\text { view, may, } \\
\text { might, often, } \\
\text { quite, possible, } \\
\text { seem, should, } \\
\text { suggest, to our } \\
\text { knowledge, } \\
\text { typical, usual- } \\
\text { ly, would }\end{array}$ & $\begin{array}{l}\text { Przebieg kliniczny nużycy może być } \\
\text { bezobjawowy. OT1 } \\
\text { Rodzaj manifestacji klinicznej nu- } \\
\dot{z} y c y \text { u pacjenta zależy prawdopo- } \\
\text { dobnie od stopnia inwazji pasoży- } \\
\text { tów Demodex. OT1 } \\
\text { Approximately } 16 \text { weeks before her } \\
\text { presentation, the patient noted an } \\
\text { ulcer with heaped-up edges in the } \\
\text { center of her vertex. HN3 } \\
\text { Lipomas can develop in various } \\
\text { parts of the body. JO1 }\end{array}$ \\
\hline $\begin{array}{l}\text { Wzmacniacze } \\
\text { (boosters) }\end{array}$ & $\begin{array}{l}\text { istotnie, jedyny, } \\
\text { określony, my- } \\
\text { śleć, potwierdzić, } \\
\text { udowodnić, wy- } \\
\text { kazać, z pewno- } \\
\text { ścia }\end{array}$ & $\begin{array}{l}\text { believe, clear- } \\
\text { ly, established, } \\
\text { indeed, never, } \\
\text { show, shown }\end{array}$ & $\begin{array}{l}\text { Udowodniono, że wraz z wiekiem } \\
\text { obniża się rezerwa jajnikowa. GP1 } \\
\text { Jedyna skuteczna metoda leczenia } \\
\text { śluzaków jest ich kardiochirurgicz- } \\
\text { ne usunięcie. KR1 }\end{array}$ \\
\hline
\end{tabular}




\begin{tabular}{|c|c|c|c|}
\hline & & & $\begin{array}{l}\text { The present case clearly demon- } \\
\text { strates that subcutaneous broncho- } \\
\text { genic cysts may be brilliantly trans- } \\
\text { illuminant. HN1 } \\
\text { We also believe that this increase } \\
\text { in ICP was probably secondary to } \\
\text { IIH based on the patient's risk } \\
\text { factors. AO1 }\end{array}$ \\
\hline $\begin{array}{l}\text { Znaczniki na- } \\
\text { stawienia (atti- } \\
\text { tude markers) }\end{array}$ & $\begin{array}{l}\text { ciekawie, cieka- } \\
\text { wy, nawet, nie- } \\
\text { zwykty, ważny }\end{array}$ & $\begin{array}{l}\text { amazing, even, } \\
\text { important, } \\
\text { interestingly, } \\
\text { remarkable, } \\
\text { unfortunately, } \\
\text { unusual }\end{array}$ & $\begin{array}{l}\text { Bardzo ciekawe badanie prezentuja } \\
\text { Arabin i wspólnicy z lat 1991-2007. } \\
\text { GP18 } \\
\text { Interestingly, several weeks prior } \\
\text { to presenting to our Emergency } \\
\text { Department, a FHA biopsy per- } \\
\text { formed in Ethiopia was suggestive } \\
\text { of lymphocytic thyroiditis, which } \\
\text { brings to light the debate of thyroid } \\
\text { PSC etiopathology. JO2 }\end{array}$ \\
\hline $\begin{array}{l}\text { Znaczniki sa- } \\
\text { moprezentacji } \\
\text { (self-mentions) }\end{array}$ & my, nasz & we, our & $\begin{array}{l}\text { W omawianym przez nas przypadku } \\
\text { czas ten wynosit } 4 \text { tygodnie. OT2 } \\
\text { Our radiologists could not precise- } \\
\text { ly diagnose the mass as a lipoma. } \\
\text { JO1 }\end{array}$ \\
\hline
\end{tabular}

Tabela 2. Wyznaczniki metadyskursu z przyktadami występowania.

W analizowanych opisach przypadków obecne jest także zwrócenie się do czytelników mające na celu włączenie ich jako uczestników argumentacji. Czyni się to poprzez stosowanie formy zaimka -my oraz czasowników w 1 osobie liczby mnogiej. Tendencja ta nie jest widoczna w anglojęzycznych opisach przypadków.

- Wykrycie MSI nie oznacza jednoznacznie, że mamy do czynienia z zespotem Lyncha. CH5

Jak pokazuje powyższa tabela, wyznaczniki dyskursu są powszechnie stosowane w opisach przypadków, w celu ,prowadzenia” czytelnika przez tekst i ułatwienia mu zrozumienia podanej informacji, a także ukazania stosunku autorów do poruszanego tematu jak również ich zaangażowania. W opisach przypadków najliczniej występują łączniki, zapewniające spójność całego tekstu, oraz znaczniki asekuracji, które pozwalają na podanie mniej precyzyjnej informacji, zmniejszenie jej siły pewności, zdystansowanie się autora do podanych faktów, oraz otwarcie pola do dyskusji dla czytelników artykułu. Analiza materiału badawczego wykazała również, iż najwięcej wyznaczników dyskursu stosuje się w sekcji Omówieniel Dyskusja, rzadziej w Opisie przypadku. Na podstawie analizy stwierdzić można, iż wyznaczniki te stosowane są częściej w artykułach anglojęzycznych, niż w polskojęzycznych. Obecność autorów jest dostrzegalna $\mathrm{w}$ obu językach, jednak anglojęzyczni autorzy tradycyjnych opisów przypadków nie angażują bezpośrednio czytelnika jako członka argumentacji, co czynią autorzy polscy. 


\section{Wnioski i dyskusja}

Opis przypadku, często niedoceniany lub nawet pomijany, jest wartościowym i pomocnym gatunkiem w dziedzinie medycyny jako materiał dydaktyczny - źródło nowej wiedzy o rzadko spotykanych lub nowych przypadkach, nowatorskich metodach diagnostyki i leczenia itp., zarówno dla lekarzy-praktyków jak i dla studentów. Zapisywanie przypadków ma bogatą historię, rozpoczynającą się od czasów starożytnych. Opisy przypadków z tamtego okresu nie miały wprawdzie obecnej formy, jednak już wtedy były używane do komunikacji pomiędzy specjalistami. W latach 80-90-tych XX wieku tradycyjny opis przypadku był często pomijany i dopiero po tym okresie zaczął odzyskiwać swoją pozycję. Od tego czasu, obok modelowych opisów, zaczęły się również pojawiać, szczególnie w piśmiennictwie anglojęzycznym, różnorodne jego odmiany, uwzględniające dodatkowo inne czynniki, tj. na przykład, perspektywę pacjenta.

Wieloaspektowe badania opisu przypadku wskazują na jego popularność oraz zainteresowanie jego udoskonalaniem i rozwijaniem. Warto zauważyć również iż w odróżnieniu od anglojęzycznej literatury, w polskim piśmiennictwie, według wiedzy autorek niniejszej pracy, nie są dostępne opracowania na temat opisu przypadku odnoszące się do jego struktury retorycznej, języka czy perspektywy pacjenta, a jedynie krótkie opracowania zawierające wskazówki, jak napisać modelowy opis przypadku. Niniejsza praca miała na celu zatem uzupełnienie tej luki w polskojęzycznych badaniach lingwistycznych. Podobne badania do zawartych w niniejszej pracy prowadziła E. DoneschJeżo (2013), która to analizowała oryginalne artykuły naukowe i ich abstrakty.

Przeprowadzona na potrzeby pracy analiza różnych odmian medycznych opisów przypadków z czasopism angielsko- i polskojęzycznych wskazała na powtarzalny schemat ich konstrukcji, który przejawiał się w podobnej strukturze retorycznej opisu zawierającej tło historyczne, zarys problemu, wskazanie jego skali, opis przypadku z przedstawieniem osoby pacjenta, szeroko pojęty proces diagnostyczno-leczniczy, dyskusję wraz z omówieniem wyników, przeglądem literatury i odwołaniem do wcześniejszych badań oraz podsumowanie zagadnienia i dalsze zalecenia. Elementy te były obecne w większości opisów, czasem jednak w różnej kolejności. Analiza lingwistyczno-gramatyczna wykazała podobieństwa w użyciu struktur gramatycznych i wskaźników metadyskursu pomiędzy językiem polskim i angielskim, wskazując jednocześnie na przewagę tychże jednostek w języku angielskim, co powoduje, iż artykuły te są bardziej spójne, a autorzy podejmują bardziej zaawansowaną interakcję z czytelnikiem. W obu językach przeważa za to użycie czasu przeszłego, obecne są również formy bezosobowe, strona bierna, formy bezczasownikowe, przymiotniki o charakterze negatywnym i zaprzeczenia.

Podsumowując analizę materiału badawczego, stwierdzić można, iż opisy przypadków w obu językach mają bardzo podobną strukturę retoryczną, zawierają te same struktury gramatyczne oraz wyznaczniki metadyskursu, a nieznaczne różnice między nimi spowodowane mogą być różnicami w dyskursie akademickim obu społeczności naukowych. Przeprowadzone przez autorki badania mogą stać się podstawą dla dalszych badań lingwistycznych w kierunku lepszego poznania odmian medycznych opisów przypadku, zarówno z perspektywy lingwistyki stosowanej, komunikacji specjalistycznej czy nawet translatoryki.

Opis przypadku, niezależnie od społeczności, języka i kraju, jest wartościowym źródłem wiedzy medycznej dla lekarzy, innych specjalistów, studentów medycyny i 
kierunków pokrewnych, ale także dla samych pacjentów. Dlatego ważnym wydaje się jego rozwój, tj. nowe odmiany, oraz doskonalenie, tj. modyfikacja tych istniejących.

\section{Bibliografia}

Adams Smith, D.E. (1984), Medical discourse: aspects of author's comment, (w:) „English for Specific Purposes” 3, 25-36.

Agha, R./ D.R. Rosin. (2010), Time for a new approach to case reports, (w:) „International Journal of Surgery Case Reports" 1(1), 1-3.

Agrimi, J./C. Crisciani. (1994), Les 'Consilia'Médicaux. Turnhout: Brepols.

Anspach, R. (1988), Notes on the sociology of medical discourse: the language of case presentation, (w:) ,Journal of Health and Social Behaviour” 29, 357-375.

Barusch, A. (2012), Refining the narrative turn: when does story-telling become research? Referat wygłoszony na konferencji Gerontological Society of America, Listopad 16, 2012, San Diego; http:/ / www.amandabarusch.com.

Berkenkotter, C. (2008), Patient tales: case histories and the uses of narrative in psychiatry. University of South Carolina Press: Colombia

Biswas, S. (2014), Beginner's guide to writing case reports, dostęp: 1.04.2014; http:/ / www.juniordr.com/ index.php/ research/ writing-case reports.html.

Browman, G.P. (1999), Essence of evidence-based medicine: a case report, (w:) „Journal of Clinical Oncology” 17, 1969-1973.

Burnum, J.F. (1989), The misinformation era: the fall of the medical record, (w:) „Annals of Internal Medicine" 110(6), 482-484.

Carleton, H./ M. Weeb. (2012), The case report in context, (w:) ,Yale Journal of Biology and Medicine" 85(1), 94-96.

Charlton, B./ F. Walston. (1998), Individual case studies in medical research, (w:) „Journal of Evaluation in Clinical Practice” 4(2), 147-155.

Charon, R. (1992), To build a case: medical histories as traditions in conflict, (w:) „Literature and Medicine” 11(1), 115-132.

Cohen, H. (2006), How to write a patient case report, (w:) „American Journal of Health-System Pharmacy" 63, 1888-1892.

Coker, E. (2003), Narrative strategies in medical discourse: constructing the psychiatric 'case' in a non-western setting, (w:) „Social Science \& Medicine” 57, 905-916.

Czapiewski, P. (2015), Specyfika artykutu case report, (w:) Ł. Budyńko/ P.Waszak (red.), Pomysł - badanie - publikacja. Poradnik naukowy dla studentów kierunków medycznych. Gdańsk, 283-288.

Dib, E./ M. Kidd/ D. Saltman. (2008), Case reports and the fight against cancer, (w:) „Journal of Medical Case Reports” 2, 39-40.

Donesch-Jeżo, E. (2013), Akademicki dyskurs medyczny w językach angielskim i polskim $w$ ujęciu lingwistycznym $i$ metodycznym : artykut naukowy $i$ jego abstrakt. Kraków.

Donnelly, W.J. (1992), Why SOAP is bad for the medical record, (w:) „Archives of Internal Medicine" 152, 481-484.

Donnelly, W.J. (1996), Taking suffering seriously: a new role for the medical case history, (w:) „Academic Medicine” 71(7), 730-737. 
Francis, G./ A. Kramer-Dahl. (2004), Grammar in the construction of medical case histories, (w:) C. Coffin/ A. Hewings/ K. O'Halloran (red.), Applying English grammar. Functional and corpus approaches. London, 172-190.

Frank, A.W. (1998), Just listening: narrative and deep illness, (w:) „Families, Systems and Health" 6, 197-212.

Garzone, G. (2011), Rethinking genres in medical communication: theoretical issues and pedagogical implications, (w:) A. Loiacono/ G. Iamartino/ K.S. Grego (red.), Teaching medical English. Methods and models. Milan, 105-131.

Green, B. / C. Johanson. (2006), How to write a case report for publication, (w:) „Journal of Chiropractic Medicine” 2(5), 72-82.

Guimaraes, C.A. (2015), Evidence based case report, (w:) „The Journal of the Brazilian College of Surgeons" 42(5), 280.

Har-El, G. (1999), Does it take a village to write a case report?, (w:) „Otolaryngology - Head and Neck Surgery" 120, 787-788.

Hunter, K.M. (1991), Doctors' stories. The narrative structure of medical knowledge. Princeton.

Hurwitz, B. (2006), Form and representation in clinical case reports, (w:) „Literature and Medicine" 25(2), 216-240.

Hyland, K. (2011), Disciplines and discourses: social interactions in the construction of knowledge, (w:) D. Starke-Meyerring i wsp. (red.), Writing in the knowledge society. West Lafayette, 193-214.

Jones-Harris, A. (2003), The evidence-based case report: a resource pack for chiropractors, (w:) „Clinical Chiropractic” 6, 73-84.

Krzemieniecki, K. (2010), Opis przypadku - sztuka zwięzłości, (w:) „Onkologia w Praktyce Klinicznej”, 6(2), 85-86.

Lingard, L./ C. Schryer / K. Garwood / M. Spafford. (2003), 'Talking the talk': school and workplace genre tension in clerkship case presentations, (w:) „Medical Education" 37, 612-620.

Ławnicka-Borońska, M. (2013), Język polski w medycynie. A guide to Polish in medical practice. Warszawa.

Martin, J.R. (1995), Text and clause: fractal resonance, (w:) „Text” 15(1), 5-42.

Martin, J.R. (2000), Analysing genre: functional parameters, (w:) „Genres and institutions: social processes in the workplace and school", F. Christie, J.R. Martin (red.), Continuum, London, 3-39.

Méndez-Cendón, B. (2009), Combinatorial patterns in medical case reports: an English-Spanish contrastive analysis, (w:) „The Journal of Specialised Translation” 11, 169-190.

Mungra, P./ T. Canziani. (2013), Lexicographic studies in medicine: academic word list for clinical case histories, (w:) „Ibérica” 25, 39-62.

Murawska, M. (2014), Interactive case reports - a case in point, (w:) H. Lankiewicz/ E. Wąsikiewicz-Firlej (red.), Languaging experiences: learning and teaching revisited. Newcastle upon Tyne, 95-115.

Neely, J. i wsp. (2008), Practical guide to understanding the value of case reports, (w:) „Otolaryngology - Head and Neck Surgery” 138, 261-264. 
Nissen, T./ R. Wynn. (2012), The recent history of the clinical case report: a narrative review, (w:) ,JRSM Short Reports”3(12), 87-91.

Nissen, T./ R. Wynn. (2014), The clinical case report: a review of its merits and limita-tions, (w) „BMC Res Notes" 7, 264-271.

Nowell-Smith, H. (1995), Nineteenth-century narrative case histories: an inquiry into stylistics and history, (w:) „CBMH/ BCHM” 12, 47-67.

Nwogu, K. (1997), The medical research paper: structure and functions, (w:) „English for Specific Purposes" 16(2), 119-138.

Papanas, N./ M.K. Lazarides. (2008), Writing a case report: polishing a gem?, (w:) „International Angiology” 27(4), 344-349.

Peile, E. (2003), Commentary: More to be learnt from the discussion than the diagnosis, (w:) „British Medical Journal” 326, 1136.

Pettinari, J. (1988), Task, talk, and text in the operating room: a study in medical discourse. Norwood.

Pierson, D. (2009), How to read a case report (or teaching case of the month), (w:) „Respiratory Care” 54(10), 1372-1378.

Pregerson, B. (2014), Ear pain and a rash in a 24-year-old man, dostęp: 01.10.2015, http:/ / reference.medscape.com/ viewarticle/ 833922? src $=$ emed_case_nl_0\&uac $=236437 \mathrm{CX} \& \mathrm{impID}=847079 \&$ faf $=1$.

Reis, S./ D. Hermoni / P. Livingstone / J. Borkan. (2002), Integrated narrative and evidence based case report: case report of paroxysmal atrial fibrillation and anticoagulation, (w:) „British Medical Journal” 325, 1018-1020.

Reiser, S.J. (1991), The clinical method in medicine part 1: learning from cases, (w:) „Annals of Internal Medicine” 114(10), 902-907.

Rowley-Jolivet, E. (2007), A genre study of If in medical discourse, (w:) K. Fløttumm (red.), Language and discipline perspectives on academic discourse. Newcastle, 184-214.

Salager-Meyer, F. (2001), From self-highlightedness to self-effacement: a genre-based study of the socio-pragmatic function of criticism in medical discourse, (w:) „LSP and Professional Communication" 1(2), 63-84.

Salager-Meyer, F./ G. Defives / C. Jensen / M. de Filipis. (1989), Function and grammatical variations in medical English scholarly papers: a genre analysis study, (w:) „Special language: from humans to thinking machines”, C. Lauren, M. Norman (red.), Multilingual Matters, Clevedon, 316-323.

Salager-Meyer, F./ M. Angeles Alcaraz Ariza. (2013), The medical narrative from a diachronic perspective (1840-2009): titling practices and authorship, (w:) M. Gotti/ C. Sancha Guinda (red.), Narratives in academic and professional genres. Bern, 293-318.

Sarangi, S./ L. Brookes-Howell L. (2006), Recontextualising the familial lifeworld in genetic counselling case notes, (w:) M. Gotti / F. Salager-Meyer (red.), Advances in medical discourse analysis: oral and written contexts. Bern, 197-225.

Smith, R. (2008a), Why do we need Cases Journal, (w:) „Cases Journal” 1(1).

Smith, R. (2008b), The policies of Cases Journal, (w:) „Cases Journal” 1(2).

Siegler, E.L. (2010), The evolving medical record, (w:) „Annals of Internal Medicine” $153,671-677$. 
Sobel, R.J. (2000), Eva's stories: recognising the poverty of the medical case history, (w:) ,Academic Medicine” 75(1), 85-89.

Taavitsainen, I./ P. Päivi. (2000), Conventions of professional writing: the medical case report in a historical perspective, (w:) ,Journal of English Linguistics”28(1), 60-76.

Treasure, T. (1995), What is the place of the clinical case report in medical publishing?, (w:) „Journal of the Royal Society of Medicine” 88, 279.

Vandenbroucke, J.P. (2001), In defence of case reports and case series, (w:) „Annals of Internal Medicine" 134(4), 330-334. 


\section{Material badawczy}

Amorim, G.M./ D. Quintella/ T. Cuzzi/ R. Rodrigues/ M. Ramos-e-Silva. (2015), Cutaneous metastasis of neuroendocrine carcinoma with unknown primary site: case report and review of the literature (w:) „Case Report in Dermatology” 7, 263-274. DR3

Bieganowska, K./ M. Miszczak-Knecht/ M. Posadowska/ M. Birbach/ A. Kowalski. (2015), Wszczepienie kardiowertera-defibrylatora i lewostronne wspótczulne odnerwienie serca u chlopca po zatrzymaniu krążenia (w:) „Kardiologia Polska” 73(2), 134. KR3

Bligh, J./ R. Farrow. (2003), A 66 year old woman with a rash: presentation (w:) „British Medical Journal" 326, 588. BM2

Bligh, J./ R. Farrow. (2003), A 66 year old woman with a rash: case progression (w:) „British Medical Journal” 326, 640. BM3

Bligh, J./ R. Farrow. (2003), A 66 year old woman with a rash: case outcome (w:) „British Medical Journal” 326, 804-805. BM4

Buainain, H./ M. Allam. (2009), Anderoderma: is it a sign of autoimmunity? (w:) „Case Reports in Dermatology” 1, 100-104. DR2

Buyskyi, O./ D. Anderson. (2016), Upper airway obstruction due to a change in altitude: first report in fifty years (w:) „Journal of Otolaryngology - Head and Neck Surgery" 45, 9-11. JO3

Dev, V./ B. Heeringa/ R. Busch. (2000), Tonsillar lipoma (w:) „Otolaryngology Head and Neck Surgery" 122, 941. HN2

Domoto, S./ O. Tagusari/ Y. Nakamura/ H. Machida. (2010), Unique haemodynamics in the patient with residua native aortic regurgitation who underwent apicoaortic bypass (w:) „European Hearth Journal” 31(23), 2959. EHJ1

Dwojak, S./ J. Hunt/ M. Cunningham. (2012), Pathology Quiz Case 3 (w:) „Archives of Otolaryngology - Head and Neck Surgery" 138(1), 99-101. AO2

Gaffey, M./ M. Friedel/ G. Fatterpekar/ J. Liu/ J. Anderson Eloy. (2012), Spontaneous cerebrospinal fluid rhinorrhea of the foramen cecum in adulthood (w:) „Archives of Otolaryngology - Head and Neck Surgery" 138(1), 79-82. AO1

Gaikward, P./ J. Muthusami/ J. Raj/ J. Rajinikanth/ G. John. (2006), Subcutaneous bronchogenic cyst (w:) „Otolaryngology - Head and Neck Surgery” 135, 951-952. HN1

Glasziou, P. (1998), Twenty year cough in a non-smoker (w:) „British Medical Journal" 516, 1160-1161. EB1

Hadasik, D./ M. Zaniewski/ G. Bierzyńska-Macyszyn/ P. Piekorz. (2005), Naczyniak jamisty glowy trzustki - opis przypadku (w:) „Chirurgia Polska” 7(4), 287-291. CHD1

Hayashi, H. i wsp. (2014), Cystic brain metastasis in non-small-cell lung cancer with ALK rearrangement (w:) „Journal of Clinical Oncology” 32(36), e122-e124. CO2

Hill, C. i wsp. (2012), Radiology Quiz Case 1 (w:) „Archives of Otolaryngology Head and Neck Surgery" 138(1), 87-89. AO3

Jedliński, I. i wsp. (2012), Bezobjawowy śluzak płatka przegrodowego zastawki trójdzielnej (w:) „Kardiologia Polska” 70, 609-611. KR1 
Kanokrungsee, S./ S. Vachiramon/ P. Sirithanabadeekul. (2014), The 'pantie' tumour (w:) „Case Report in Dermatology” 6, 274-278. DR1

Konstanty-Kalandyk, J./ K. Wierzbicki/ K. Bartuś/ J. Sadowski. (2013), Zawał serca spowodowany materiałem zatorowym jako pierwsza manifestacja lewego przedsionka (w:) „Kardiologia Polska” 71 (4), 403-405. KR4

Kubiak, M./ D. Kaczmarczyk/ R. Kubiak/ A. Morawiec-Sztandera. (2014), Nużyca jako podejrzenie zmiany nowotworowej skóry twarzy - opis przypadku (w:) „Otorynolaryngologia" 13(4), 224-226. OT1

Kumar, A. i wsp. (2008), Multidrug resistant tuberculosis co-extsting with aspergilloma and invasive aspergillosis in a 50 year old diabetic woman: a case report (w:) „Cases Journal” 1, 303-306. CR2

Lauda-Świeciak, A. i wsp. (2010), Holoprosencefalia - przedmózgowie jednokomorowe-opis przypadku (w:) „Ginekologia Polska” 81, 940-943. GP10

Lui, J./ M. Khalil/ S. Chandarana. (2014), Primary squamous cell of the thyroid - an abbreviated clinical presentation (w:) „Journal of Otolaryngology - Head and Neck Surgery" 43, 17-20. JO2

Mąka, B. i wsp. (2013), Rzadka postać zespołu Lyncha z trzema synchronicznymi, o podobnym zaawansowaniu, ogniskami gruczolakoraka okrężnicy (w:) „Chirurgia Polska" 15(1), 88-92. CH5

Moszura, T. i wsp. (2013), Leczenie hybrydowe noworodka z przerwanym łukiem aorty i przeciwwskazaniami do krążenia pozaustrojowego: opis przypadku z uwzględnieniem 1,5-rocznej obserwacji (w:) „Kardiologia Polska” 71(4), 396-398. KR0

Narożny, W./ A. Pustkowski/ J. Kuczkowski/ P. Łopatiuk. (2014), Postać wrzodzejaco-węzłowa tularemii głowy i szyi u 12-letniego dziecka (w:) „Otorynolaryngologia" 13(4), 231-235. OT2

Neyns, B./ S. Cordera/ E. Joosens/ P. Nader. (2008), Non-Hodgkin's lymphoma in patients with glioma treated with temozolomide (w:) „Journal of Clinical Oncology” 26(27), 4518-4519. CO0

Oh, J.Y. (2010), Keratoconus associated with choroidal neovascularization: a case report (w:) „Journal of Medical Case Reports” 4, 58-61. CR1

Ozturk, M./ K. Ila/ A. Kara/ M. Iseti. (2013), Fibrolipoma of the nasa septum; report of the first case (w:) „Journal of Otolaryngology - Head and Neck Surgery” 42, 11-14. JO1

Parker, M. (2000), Managing an elderly patient with a fractured femur (w:) „British Medical Journal" 320, 102-103. EB2

Pucher, B., i wsp. (2015), Fibromatosis juvenile u dzieci - opisy przypadków (w:) „Otorynolaryngologia” 14(1), 48-50. OT3

Reis, S./ D. Hermoni/ P. Livingstone/ J. Borkan. (2002), Case report of paroxysmal atrial fibrillation and anticoagulation (w:) „British Medical Journal” 325, 10181020. BM1

Serdyńska-Sztuster, M./ K. Ożegowska/ M. Hołysz/ P. Hagodziński/ L. Pawelczyk. (2016), Przewidywanie słabej odpowiedzi na kontrolowana hiperstymulacje jajników na podstawie polimortizmów genu GDF-9 - opis przypadku (w:) „Ginekologia Polska” 87, 71-75. GP1 
Serrano, C./ A. Garcia/ I. Brana/ A. Perez-Benavente/ A. Oaknin. (2010), Angiosarcoma of the ovary: is it always a lethal disease? (w:) ,Journal of Clinical Oncology" 28(33), e675-e677. CO1

Wolski, H./ A. Seremak-Mrozikiewicz/ A.Woyciechowska/ K. Drews. (2014), Odroczony poród w ciąży trojaczej - opis przypadku (w:) „Ginekologia Polska” 85, 466-471. GP18

Wong, A./ M. Johns/ T. Teknos. (2003), Marjolin's ulcer arising in a previously grafted burn of the scalp (w:) ,Otolaryngology - Head and Neck Surgery” 128(6), 915916. HN3

Wroński, K./ A. Lachowski. (2014), Leczenie chirurgiczne raka żoładka u świadka Jehowy. Opis przypadku i analiza prawna sytuacji (w:) „Chirurgia Polska” 16(2), 97-102. CH2

Patient Experience Case Studies. Matthew's story: a child's experience of cancer diagnosis and treatment, 2009, Regina: KPMG. PE1

Patient Experience Case Studies. Walter's story: a Metis man living with chronic health condition, 2009, Regina: KPMG. PE2 